Case Report

\title{
Snake-Bite with Disseminated Intravascular Coagulation (DIC) and Stage II Hypertension
}

\author{
Hendra Subroto*, Leni Lismayanti** \\ *Clinical Pathology Department \\ Faculty of Medicine Maranatha Christian University \\ Jalan Prof. drg. Suria Sumantri MPH No. 65 Bandung 40164 Indonesia \\ ** Clinical Pathology Department \\ Faculty of Medicine Padjadjaran University - Hasan Sadikin Hospital \\ Jl. Pasteur no 38 Bandung 40161 Indonesia \\ Email: henzu_inter@yahoo.co.id
}

\begin{abstract}
Snake-bite is an important medical emergency case and caused of many hospital admission especially in the rural area, forests, plantations and swamps. Despite its importance, there have been fewer proper data of snake-bite incidence in Indonesia. World Health Organization estimate that at least 421,000 envenomings and 20,000 deaths from snakebites occur each year, especially in South and South East Asia and sub-Saharan Africa. The authors report a case of a 76-year-old man came to Hasan Sadikin Hospital with chief complaint wound in his right hand and right forearm from snake-bite. Snake-bites can cause DIC because the venom activates the coagulation system and cause fibrinolysis which occurs in less than 24 hours. Laboratory results, we found abnormalities such as anemia, thrombocytopenia, hypofibrinogenemia, and increased levels of D-dimer. Patients were treated for 8 days and then allowed to go home. Snake-bite is an occupational disease of farmers, plantation workers, herdsmen, fishermen, other. Snake bite cases require prompt and comprehensive management so as to minimize the possibility of disability and death.
\end{abstract}

Keywords: snake bite, DIC, hypertension 


\title{
Vulnus Morsum Serpentum dengan Disseminated Intravascular Coagulation (DIC) dan Hipertensi Stage II
}

\author{
Hendra Subroto*, Leni Lismayanti** \\ *Bagian Patologi Klinik \\ Fakultas Kedokteran Universitas Kristen Maranatha \\ Jalan Prof. drg. Suria Sumantri MPH No. 65 Bandung 40164 Indonesia \\ **Departemen Patologi Klinik \\ Fakultas Kedokteran Universitas Padjadjaran-RSUP Dr. Hasan Sadikin Bandung \\ J1. Pasteur no 38 Bandung Indonesia \\ Email: henzu_inter@yahoo.co.id
}

\begin{abstract}
Abstrak
Kasus gigitan oleh ular termasuk kasus kegawatan yang sering dijumpai di Unit Gawat Darurat, terutama yang berada di area persawahan, hutan, perkebunan, dan rawa. Tidak ada data yang pasti mengenai jumlah kasus gigitan ular di Indonesia. Menurut WHO, diperkirakan terdapat 421 ribu kasus gigitan ular, dengan 20 ribu kematian terjadi di Asia Selatan, AsiaTenggara dan Sub Sahara Afrika setiap tahunnya. Penulis melaporkan kasus seorang lakilaki berusia 76 tahun datang ke Rumah Sakit Hasan Sadikin Bandung dengan keluhan utama luka di tangan kanan dan lengan atas kanan karena digigit ular. Gigitan ular berbisa dapat menyebabkan DIC karena bisa ular mengaktivasi sistem koagulasi dan menyebabkan terjadinya fibrinolisis. Secara laboratoris, ditemukan kelainan seperti anemia, trombositopenia, hipofibrinogenemia, dan peningkatan kadar D-Dimer. Pada penderita proses ini terjadi dalam waktu kurang dari 24 jam. Penderita dirawat selama 8 hari kemudian diperbolehkan pulang.Laporan kasus ini dibuat untuk memperluas wawasan kita sekalian bahwa kasus gigitan ular merupakan kasus kegawatan yang terkait pekerjaan, misalnya petani, orang yang bekerja di perkebunan, gembala ternak, nelayan, dan lainnya. Kasus gigitan ular memerlukan penatalaksanaan yang cepat dan komprehensif, sehingga dapat meminimalkan kemungkinan kecacatan dan kematian.
\end{abstract}

Kata kunci: vulnus morsum serpentum, DIC, hipertensi 
Case Report

\section{Pendahuluan}

Kasus gigitan oleh ular termasuk kasus kegawatan yang sering dijumpai di Unit Gawat Darurat terutama yang berada di area persawahan, hutan, perkebunan, dan rawa. Tidak ada data yang pasti mengenai jumlah kasus gigitan ular di Indonesia. Menurut WHO, diperkirakan terdapat 421 ribu kasus gigitan ular, dengan 20 ribu kematian terjadi di Asia Selatan, AsiaTenggara dan Sub Sahara Afrika setiap tahunnya. ${ }^{1}$

Angka morbiditas dan mortalitas gigitan ular bergantung dari jenis spesies ular, jumlah dan jenis bisa yang masuk ke dalam tubuh, dan ketersediaan serum anti bisa ular. Bisa ular beracun dapat menyebabkan kecacatan maupun kematian. Gigitan ular dapat menjadi keadaan yang mengancam jiwa jika tidak mendapat pertolongan dengan baik.

Ular merupakan jenis hewan melata yang banyak terdapat di Indonesia. Spesies ular dapat dibedakan atas ular berbisa dan ular tidak berbisa. Ciri-ciri ular tidak berbisa adalah bentuk kepala segiempat panjang, gigi taring kecil, dan bekas gigitan: luka halus berbentuk lengkungan. Ciri-ciri ular berbisa adalah bentuk kepala segitiga, dua gigi taring besar di rahang atas, dan bekas gigitan: dua luka gigitan utama akibat gigi taring. ${ }^{1}$ Ular berbisa memiliki sepasang taring pada bagian rahang atas. Pada taring tersebut terdapat saluran untuk menginjeksikan bisa ke dalam tubuh mangsanya secara subkutan atau intramuskular. Bisa adalah suatu zat atau substansi yang berfungsi untuk melumpuhkan mangsa dan sekaligus juga berperan untuk pertahanan diri. Bisa ular dihasilkan oleh kelenjar parotid yang terletak di bagian bawah kepala belakang mata. Efek toksik bisa ular pada saat menggigit mangsanya bergantung dari spesies, ukuran ular, jenis kelamin, usia, dan efisiensi mekanik gigitan (apakah hanya satu atau kedua taring menusuk kulit), serta banyaknya serangan yang terjadi. ${ }^{1}$

Berdasarkan sifatnya pada tubuh mangsa, bisa ular dapat dibedakan menjadi bisa hemotoksik, yaitu bisa yang dapat mempengaruhi jantung dan sistem pembuluh darah; bisa neurotoksik, yaitu bisa yang dapat mempengaruhi sistem saraf dan otak; dan bisa sitotoksik,yaitu bisa yang hanya bekerja pada lokasi gigitan. Gejala dan tanda-tanda gigitan ular akan bervariasi sesuai spesies ular yang menggigit dan banyaknya bisa yang diinjeksikan pada korban. Gejala dan tanda-tanda tersebut antara lain adalah tanda 
Case Report

gigitan taring (fang marks), nyeri lokal, pendarahan lokal, memar, pembengkakan kelenjar getah bening, radang, melepuh, infeksi lokal, dan nekrosis jaringan. ${ }^{1}$

Secara laboratoris, dapat ditemukan kelainan seperti anemia karena hemolisis intravaskular, trombositopenia, hematuria, hipofibrinogenemia, peningkatan kadar DDimer. ${ }^{1}$ Bisa ular terdiri dari $90 \%$ protein. Protein pada bisa ular terdiri dari enzim, toksin non-enzimatik polipeptida, dan protein non toksin (nerve growth factor). Komposisi dan fungsi bisa ular dapat dilihat pada tabel 1 .

Tabel 1 Komposisi Bisa Ular

\begin{tabular}{ll}
\hline Komposisi Bisa Ular & Fungsi \\
\hline Enzim & Enzim proteolitik, dan sitotoksin polipeptida. \\
$\begin{array}{l}\text { Hyaluronidase } \\
\text { Zinc metalloproteinase haemorrhagins }\end{array}$ & $\begin{array}{l}\text { Merusak endotel pembuluh darah, } \\
\text { menyebabkan perdarahan. }\end{array}$ \\
Enzim prokoagulan & $\begin{array}{l}\text { Aktivasi faktor X, protrombin. } \\
\text { Ferusak mitokondria, sel darah merah, }\end{array}$ \\
& $\begin{array}{l}\text { leukosit, trombosit, saraf perifer, otot lurik, } \\
\text { endotel pembuluh darah, menyebabkan }\end{array}$ \\
& pelepasan histamin dan antikoagulan. \\
Toksin non-enzimatik polipeptida & \\
(neurotoksin) & Ikatan dengan reseptor asetilkolin pada motor \\
a-bungarotoxin, cobrotoxin, crotoxin, taipoxin & end plate. Mencegah pelepasan \\
& neurotransmitter. \\
Protein non toksin & Nerve growth factor
\end{tabular}

\section{Laporan Kasus}

Seorang laki-laki berusia 76 tahun datang ke Unit Gawat Darurat RS Hasan Sadikin Bandung pada tanggal 14 Mei 2011 dengan keluhan utama luka di tangan kanan dan lengan atas kanan karena digigit ular. Satu hari sebelum masuk rumah sakit, tangan kanan dan lengan atas kanan penderita digigit ular saat sedang bekerja di sawah. Ular berwarna coklat (seperti batik), bentuk kepala segitiga, panjang $30 \mathrm{~cm}$. Pada tangan kanan dan lengan atas kanan sekitar luka tampak bengkak kemerahan dan nyeri dirasakan menjalar sampai ke bahu. Tidak ada mimisan, tidak ada gusi berdarah, tidak ada perdarahan di bawah kulit, tidak ada buang air besar berwarna hitam. Karena keluhannya penderita berobat ke RSUD Subang, diberikan obat serum anti bisa ular dan kemudian dirujuk ke RS Hasan Sadikin Bandung. 
Case Report

Pada pemeriksaan fisik didapatkan kesadaran penderita compos mentis, dengan tekanan darah 160/80 mmHg, nadi 80x/menit, respirasi 20x/menit, dan suhu $37,2{ }^{\circ} \mathrm{C}$. Pada ekstremitas didapat akral hangat, capillary refill $<2$ detik. Pada regio dorsum manus ditemukan bengkak dan nyeri sampai siku, bullae (+), hiperpigmentasi (+), nyeri tekan (+). Pada regio 1/3 proksimal humerus ditemukan bengkak dan nyeri sampai siku. Bullae (+), hiperpigmentasi (+), nyeri tekan (+).

Pada tanggal 14 Mei 2011, dilakukan pemeriksaan laboratorium hematologi rutin di UGD RSUD Subang. Hasil pemeriksaan laboratorium dapat dilihat pada tabel 2.

Tabel 2 Hasil Pemeriksaan Laboratorium di Emergensi Umum RSUD Subang Tanggal 14 Mei 2011 (Jam Tidak Diketahui)

\begin{tabular}{lcccc}
\hline \multicolumn{1}{c}{ Pemeriksaan } & Hasil & Nilai Rujukan & Satuan & Interpretasi \\
\hline Hematologi & & & & \\
Hemoglobin & 12,5 & $12-16$ & $\mathrm{~g} / \mathrm{dL}$ & $\mathrm{N}$ \\
Lekosit & $* 12.800$ & $4.000-10.000$ & $/ \mathrm{mm}^{3}$ & $\uparrow$ \\
Hematokrit & 35 & $35-50$ & $\%$ & $\mathrm{~N}$ \\
Trombosit & $* 15.000$ & $150.000-450.000$ & $/ \mathrm{mm}^{3}$ & $\downarrow$ \\
RBC & 4,33 & $3,5-6,0$ & $\mathrm{juta} / \mu \mathrm{L}$ & $\mathrm{N}$ \\
MCV & - & - & $\mathrm{fL}$ & - \\
MCH & - & - & $\mathrm{pg}$ & - \\
MCHC & - & - & $\%$ & - \\
\hline
\end{tabular}

Pada tanggal 15 Mei 2011 jam 04.00, dilakukan pemeriksaan laboratorium hematologi rutin, kimia, dan koagulasi di UGD RS Hasan Sadikin. Hasil pemeriksaan laboratorium dapat dilihat pada tabel 3 . 
Tabel 3 Hasil Pemeriksaan Laboratorium Di UGD RS Hasan Sadikin Tanggal 15 Mei 2011 (Jam 04.00)

\begin{tabular}{|c|c|c|c|c|}
\hline Pemeriksaan & Hasil & Nilai Rujukan & Satuan & Interpretasi \\
\hline Masa Protrombin & 12,9 & $9,8-13,8$ & detik & $\mathrm{N}$ \\
\hline INR & 1,09 & $0,83-1,17$ & & $\mathrm{~N}$ \\
\hline APTT & 25,5 & $15,9-35,9$ & detik & $\mathrm{N}$ \\
\hline Fibrinogen & $* 59,9$ & $200-300$ & $\mathrm{mg} / \mathrm{dL}$ & $\downarrow$ \\
\hline D-Dimer Kuantitatif & $* 1,8$ & $<0,3$ & $\mathrm{mg} / \mathrm{dL}$ & $\uparrow$ \\
\hline \multicolumn{5}{|l|}{ Hematologi: } \\
\hline Hemoglobin & $* 11,8$ & $13,5-17,5$ & $\mathrm{~g} / \mathrm{dL}$ & $\downarrow$ \\
\hline Hematokrit & $* 33$ & $40-52$ & $\%$ & $\downarrow$ \\
\hline Lekosit & 11.000 & $4.400-11.300$ & $/ \mathrm{mm}^{3}$ & $\mathrm{~N}$ \\
\hline Eritrosit & $* 3,82$ & $4.5-6,5$ & juta/uL & $\downarrow$ \\
\hline Trombosit & $* 16.000$ & $150.000-450.000$ & $/ \mathrm{mm}^{3}$ & $\downarrow$ \\
\hline $\mathrm{MCV}$ & 87,4 & $80-100$ & $\mathrm{fL}$ & $\mathrm{N}$ \\
\hline $\mathrm{MCH}$ & 30,9 & $26-34$ & $\mathrm{Pg}$ & $\mathrm{N}$ \\
\hline $\mathrm{MCHC}$ & 35,3 & $32-36$ & $\%$ & $\mathrm{~N}$ \\
\hline \multicolumn{5}{|l|}{ Kimia } \\
\hline AST (SGOT) & 43 & $<50$ & $\mathrm{U} / \mathrm{L} 37^{\circ} \mathrm{C}$ & $\mathrm{N}$ \\
\hline ALT (SGPT) & 14 & $<50$ & $\mathrm{U} / \mathrm{L} 37^{\circ} \mathrm{C}$ & $\mathrm{N}$ \\
\hline Ureum & 23 & $15-50$ & $\mathrm{mg} / \mathrm{dl}$ & $\mathrm{N}$ \\
\hline Kreatinin & 0,81 & $0,7-1,2$ & $\mathrm{mg} / \mathrm{dl}$ & $\mathrm{N}$ \\
\hline $\begin{array}{l}\text { Glukosa darah } \\
\text { sewaktu }\end{array}$ & 126 & $<140$ & $\mathrm{mg} / \mathrm{dl}$ & $\mathrm{N}$ \\
\hline Natrium & $* 128$ & $135-145$ & $\mathrm{mEq} / \mathrm{L}$ & $\downarrow$ \\
\hline Kalium & 3,9 & $3,6-5,5$ & $\mathrm{mEq} / \mathrm{L}$ & $\mathrm{N}$ \\
\hline Klorida & $* 91$ & $98-108$ & $\mathrm{mEq} / \mathrm{L}$ & $\downarrow$ \\
\hline
\end{tabular}

Penderita kemudian dirawat di ruang Melati RS Hasan Sadikin. Rangkuman hasil pemeriksaan laboratorium selama perawatan dapat dilihat pada tabel 4 .

Tabel 4 Hasil Pemeriksaan Laboratorium Selama Perawatan di Ruang Melati RS Hasan Sadikin

\begin{tabular}{lccccc}
\hline \multicolumn{1}{c}{ Pemeriksaan } & $\begin{array}{c}\mathbf{1 6} \text { Mei 2011 } \\
\text { jam 05.29 }\end{array}$ & $\begin{array}{c}\mathbf{1 7} \text { Mei 2013 } \\
\text { jam 05.53 }\end{array}$ & $\begin{array}{c}\text { 18 Mei 2011 } \\
\text { jam 10.50 }\end{array}$ & $\begin{array}{c}\text { 19 Mei 2011 } \\
\text { jam 05.56 }\end{array}$ & Satuan \\
\hline Masa Protrombin & - & 12,1 & - & 11,4 & detik \\
INR & - & 0,93 & - & 0,82 & \\
APTT & - & 28,0 & - & 25,9 & detik \\
Fibrinogen & - & 240,4 & - & - & $\mathrm{mg} / \mathrm{dL}$ \\
D-Dimer Kuantitatif & - & 0,9 & - & - & $\mathrm{mg} / \mathrm{dL}$ \\
Hematologi: & & & & & \\
Hemoglobin & $* 10,1$ & - & $* 9.0$ & - & $\mathrm{g} / \mathrm{dL}$ \\
Hematokrit & $* 28$ & - & $* 29$ & - & $\%$ \\
Lekosit & 6.200 & - & $* 3.800$ & - & $/ \mathrm{mm}{ }^{3}$ \\
Eritrosit & $* 3,82$ & - & $* 3,15$ & - & $\mathrm{Juta} / \mathrm{uL}$ \\
Trombosit & $* 114.000$ & - & $* 184.000$ & - & $/ \mathrm{mm}{ }^{3}$ \\
MCV & 86,3 & - & 90,8 & - & $\mathrm{fL}$ \\
MCH & 31,1 & - & 28,6 & - & $\mathrm{Pg}$ \\
MCHC & 34,3 & - & 31,5 & - & $\%$ \\
& & & & & \\
\hline Kimia & $* 133$ & - & - & - & $\mathrm{mEq} / \mathrm{L}$ \\
Natrium & 4,0 & - & - & - & $\mathrm{mEq} / \mathrm{L}$ \\
Kalium & &
\end{tabular}


Penderita mendapat cairan RL $1500 \mathrm{~mL} / 24$ jam, serum anti bisa ular sebanyak 4 ampul, anti tetanus serum 1500 IU i.m, anti tetanus serum 1500 IU i.m, tetanus toxoid $0,5 \mathrm{ml}$ i.m, metronidazole $3 \times 500 \mathrm{mg}$ i.v, parasetamol 3x500 mg p.o, ceftriaxon 1x2 gr i.v (dalam D5\% $100 \mathrm{ml}$ ), rencana pemberian heparin 3x5000 IU s.c. tanggal 19 Mei 2011 jam 18.00 (pemberian heparin ditunda), transfusi cryoprecipitate 4 unit yang diberikan tanggal 15 Mei 2011 jam 20.35, transfusi trombosit 4 unit yang diberikan tanggal 15 Mei 2011 (I: jam 18.50; II: 19.05; III: 19.20; IV: 19.35), captopril 3x12,5 mg peroral, diet protein 1 gram/KgBB/hari, dan kompres luka dengan $\mathrm{NaCl}$ 0,9\%.

Tabel 5 Pemberian Serum Anti Bisa Ular (Sabu) Selama Perawatan

\begin{tabular}{ccc}
\hline No. & Tanggal & \\
\hline 1. & 15 Mei 2011 & SABU 4 ampul dalam D5\% $500 \mathrm{~mL}$ \\
2. & 16 Mei 2011 & SABU 4 ampul dalam NaCL0,9\% 500 mL \\
3. & 17 Mei 2011 & SABU 4 ampul dalam NaCL0,9\% 500 mL \\
4. & 18 Mei 2011 & SABU 4 ampul dalam NaCL0,9\% 500 mL \\
5. & 19 Mei 2011 & SABU 4 ampul dalam NaCL0,9\%500 mL \\
\hline
\end{tabular}

\section{Diskusi}

Pada anamnesis didapatkan tangan kanan dan lengan atas kanan penderita digigit ular satu hari sebelum masuk rumah sakit. Ular berwarna coklat (seperti batik), bentuk kepala segitiga, panjang $30 \mathrm{~cm}$. Kemungkinan ular yang menggigit penderita merupakan ular berbisa. Karena keluhannya penderita berobat ke RSUD Subang, diberikan obat serum anti bisa ular (SABU) dan kemudian dirujuk ke RS Hasan Sadikin. Tidak ada informasi jam berapa penderita digigit ular dan jam berapa penderita dibawa ke RSUD Subang.

Pada pemeriksaan fisik didapatkan tekanan darah penderita 160/80 $\mathrm{mmHg}$. Tekanan darah penderita termasuk hipertensi stage II. Pada anamnesis tidak ditanyakan mengenai riwayat pengobatan hipertensi penderita. ${ }^{3}$ Pernafasan penderita dalam batas normal (20 kali/menit). Hal ini menandakan tidak terjadi komplikasi paralisis otot-otot pernafasan akibat pengaruh bisa neurotoksik. Pada pemeriksaan fisik didapatkan tangan kanan dan lengan atas kanan sekitar luka tampak bengkak kemerahan dan nyeri dirasakan menjalar sampai ke bahu. Keluhan ini merupakan efek sitotoksik dan neurotoksik bisa ular pada daerah gigitan. 
Case Report

Pada pemeriksaan laboratorium didapatkan penurunan kadar hemoglobin; pada saat berobat di RSUD Subang 12,5 dan pada pemeriksaan di emergensi umum RS Hasan Sadikin menjadi 11,8 g/dL (13,5-17,5 g/dL). Belum diketahui penurunan kadar hemoglobin disebabkan karena pengaruh bisa ular atau karena perbedaan metode pemeriksaan kadar hemoglobin di RSUD Subang dan RS Hasan Sadikin. Pemeriksaan morfologi darah tepi dapat digunakan untuk melihat kelainan morfologi eritrosit yaitu adanya fragmentosit (schistosit) akibat proses hemolisis intravaskuler, namun pemeriksaan ini tidak dilakukan. Bila berdasarkan "rule of three" dimana hematokrit = 3 kali hemoglobin $(10,1 \times 3=30,3 \%)$, pada kenyataannya pada tanggal 16 Mei 2011 kadar hematokrit (28\%) di bawah 30,3\% maka sebaiknya melihat morfologi darah tepi untuk melihat adanya fragmentosit. ${ }^{4}$

Pada penderita didapatkan peningkatan jumlah leukosit $\left(12.800 / \mathrm{mm}^{3}\right)$ pada pemeriksaan laboratorium di RSUD Subang tanggal 14 Mei 2011. Pada pemeriksaan laboratorium di RS Hasan Sadikin pada tanggal 16 Mei $2011\left(6.200 / \mathrm{mm}^{3}\right)$ dan 18 Mei $2011\left(3.800 / \mathrm{mm}^{3}\right)$ didapatkan jumlah leukosit penderita mengalami penurunan. Penurunan jumlah leukosit kemungkinan disebabkan karena pengaruh pengenceran oleh cairan RL sebanyak 1500 mL/24 jam yang diberikan melalui infus sejak tanggal 15 Mei 2011.

Parameter trombosit mengalami penurunan yaitu $15.000 / \mathrm{mm}^{3}(150.000-$ $450.000 / \mathrm{mm}^{3}$ ). Trombositopenia terjadi karena penggunaan trombosit pada proses DIC akut akibat aktivasi oleh bisa ular. Trombosit penting dalam pembentukan sumbat hemostasis dan menjaga hemostasis normal. Transfusi 4 unit trombosit diberikan pada saat penderita di emergensi umum tanggal 15 Mei 2011 (I: jam 18.50; II: 19.05; III: 19.20; IV: 19.35). Indikasi transfusi trombosit pada penderita adalah penderita dengan DIC dengan jumlah trombosit kurang dari 50.000/mm $\mathrm{m}^{3,4-8}$

Menurut American Association of Blood Bank (AABB) ${ }^{7}$ pemberian transfusi trombosit pada 15 menit pertama diberikan dengan kecepatan $2-5 \mathrm{~mL} / \mathrm{menit}$, kemudian setelah 15 menit kecepatan pemberian transfusi trombosit $300 \mathrm{~mL} / \mathrm{jam}$. Pada kasus ini pemberian transfusi satu unit trombosit di ruang emergensi umum selesai dalam 15 menit. Setiap unit trombosit yang berasal dari whole blood mempunyai 5,5 x $10^{5}$ trombosit dan dapat meningkatkan jumlah trombosit $5.000-10.000 / \mathrm{mm}^{3}$ pada orang dewasa dengan berat badan $70 \mathrm{Kg}$. Berat badan penderita tidak diketahui. Penderita 
Case Report

mendapat total 4 unit transfusi trombosit dengan harapan dapat meningkatkan trombosit $20.000-40.000 / \mathrm{mm}^{3}$. Pemeriksaan laboratorium untuk mengetahui jumlah trombosit post transfusi pada tanggal 16 Mei 2011 jam 05.29. Jumlah trombosit post transfusi $114.000 / \mathrm{mm}^{3}$. Jumlah trombosit yang diharapkan setelah transfusi trombosit adalah $36.000-56.000 \mathrm{~mm}^{3}$, tetapi pada kasus ini jumlah trombosit $114.000 \mathrm{~mm}^{3}$. Hal ini dapat disebabkan karena proses trombopoiesis oleh sumsum tulang masih baik. ${ }^{4-8}$

Disseminated intravascular coagulation (DIC) didefinisikan sebagai kelainan sistemik trombohemoragik, merupakan suatu kondisi klinis sekunder terhadap penyakit dasarnya, dan dihubungkan dengan terdapatnya bukti berupa gejala klinik dan parameter laboratorium yaitu: aktivasi koagulasi, aktivasi fibrinolisis, konsumsi inhibitor, dan penanda biokimia yang membuktikan adanya kerusakan atau kegagalan organ tahap akhir. ${ }^{4,5}$

Secara umum disseminated intravascular coagulation dapat dibagi menjadi dua yaitu: compensated DIC atau non-overt DIC dan decompensated DIC atau overt DIC. Proses disseminated intravascular coagulation biasanya diawali dengan keadaan compensated DIC kemudian berlanjut dengan decompensated DIC. ${ }^{4,5}$ Pada keadaan compensated DIC terdapat 2 tahap, yaitu pertama hiperkoagulabilitas serta kedua fibrinolisis sekunder. Pada keadaan compensated DIC ditandai dengan terjadinya aktivasi koagulasi sehingga terjadi pemakaian trombosit dan faktor-faktor koagulasi lebih dari normal akan tetapi hal tersebut masih dapat terkompensasi sehingga bila dilakukan pemeriksaan parameter hemostasis masih dapat memberikan hasil normal.

Pada kasus ini bisa ular mengaktivasi sistem koagulasi dan terjadinya fibrinolisis dalam waktu kurang dari 24 jam. Dapat dilihat dari kadar fibrinogen menurun dan kadar D-Dimer meningkat. Penderita berada dalam tahap compensated DIC, dapat dilihat dari nilai PT dan aPTT masih dalam batas normal. Aktivasi koagulasi dan fibrinolisis oleh bisa ular dapat terjadi 30 menit setelah gigitan ular berbisa., ${ }^{4,5,10}$

Pada pemeriksaan laboratorium penderita didapatkan hasil pemeriksaan masa protrombin (PT), international normalized ratio (INR) dalam batas normal. Pemeriksaan PT untuk menilai aktivitas faktor koagulasi melalui jalur ekstrinsik dan jalur bersama yaitu factor pembekuan VII, X, V, protrombin, fibrinogen, dan faktor jaringan. ${ }^{4,5,11}$ 
Pada pemeriksaan laboratorium didapatkan hasil pemeriksaan activated Partial Tromboplastin Time (aPTT) dalam batas normal. Pemeriksaan aPTT untuk menilai aktifitas faktor koagulasi melalui jalur intrinsik dan jalur bersama yaitu factor pembekuan XII, XI, IX, VIII, X, V, protrombin, dan fibrinogen. ${ }^{4,5,11}$

Pada pemeriksaan laboratorium didapatkan kadar fibrinogen penderita menurun. Fibrinogen adalah glikoprotein dengan berat molekul 340.000 dalton. Fibrinogen disintesis di hati (1,7-5 g/hari). Penurunan kadar fibrinogen pada penderita dapat disebabkan karena perubahan fibrinogen menjadi fibrin oleh bisa ular. ${ }^{5,11}$

Cryoprecipitate adalah fresh frozen plasma yang telah dicairkan pada suhu 1$6^{\circ} \mathrm{C}$, kemudian supernatan dipisahkan dan sedimennya dibekukan kembali. Transfusi cryoprecipitate harus diberikan segera. Transfusi cryoprecipitate diberikan pada penderita dengan DIC, transfusi masif, penderita dengan kelainan defisiensi fibrinogen. Kadar fibrinogen plasma minimal $100 \mathrm{mg} / \mathrm{dL}$ diperlukan untuk proses hemostasis yang baik, sedangkan kadar fibrinogen penderita rendah yaitu $59,9 \mathrm{mg} / \mathrm{dL}$ sehingga merupakan indikasi transfusi cryoprecipitate. ${ }^{6,8,11}$

Setiap $15 \mathrm{~mL} /$ unit cryoprecipitate biasanya mengandung faktor VIII $100 \mathrm{IU}$, kadar fibrinogen 100-250 mg, faktor von Willebrand (vWF) dan faktor XIII. Satu unit cryoprecipitate dapat meningkatkan kadar fibrinogen 100-250 mg. Transfusi cryoprecipitate 4 unit diberikan pada saat penderita di emergensi umum tanggal 15 Mei 2011 mulai jam 20.35. Pemeriksaan laboratorium untuk memantau pemberian transfusi cryoprecipitate pada tanggal 17 Mei 2011 jam 05.59. Kadar fibrinogen post transfusi $240,4 \mathrm{mg} / \mathrm{dL}$. Kadar fibrinogen yang diharapkan setelah transfusi cryoprecipitate adalah 400-1000 mg/dL, sedangkan kadar fibrinogen pada tanggal 17 Mei 2011 yaitu 240,4 mg/dL. Hal ini dapat disebabkan karena pada tanggal 15 Mei 2011 sampai tanggal 17 Mei 2011 masih terjadi proses DIC. Menurut $\mathrm{AABB}^{7}$ pemantauan transfusi cryoprecipitate yaitu pemeriksaan kadar fibrinogen sebaiknya dilakukan dalam 8 jam setelah transfusi. Penderita baru dilakukan pemeriksaan fibrinogen pada tanggal $17 \mathrm{Mei}$ 2011 (kurang lebih 48 jam). Hal ini dapat memberikan informasi yang kurang tepat mengenai kadar fibrinogen penderita setelah transfusi cryoprecipitate. ${ }^{6,8,11}$

Fresh frozen plasma (FFP) merupakan plasma yang disimpan pada suhu $-18^{\circ} \mathrm{C}$ dalam 6-8 jam setelah pengambilan dan dapat disimpan hingga 1 tahun. Sebelum digunakan, FFP dicairkan selama 20-30 menit dan harus segera diberikan karena pada 


\section{Case Report}

FFP terdapat faktor V dan faktor VIII merupakan faktor labil yang akan menurun aktivitasnya. Fresh frozen plasma mengandung fibrinogen $2 \mathrm{mg} / \mathrm{mL}$; faktor II $87 \%$; faktor V 89\%; faktor VII 88\%; faktor VIII 56\%; faktor IX 70\%; faktor X 89\%; $a$ disintegrin and metalloproteinase with a thrombospondin type 1 motif, member 13 (ADAMTS-13) 94\%; von Willebrand factor 97\%; faktor XIII 91\%. Indikasi pemberian FFP adalah transplantasi dan penyakit hepar, perdarahan masif, DIC, mengatasi efek warfarin, dan thrombotic thrombocytopenic purpura (TTP). Pada kasus ini tidak diberikan FFP karena dapat menambah beban volume plasma penderita., ${ }^{6,8,11,12}$

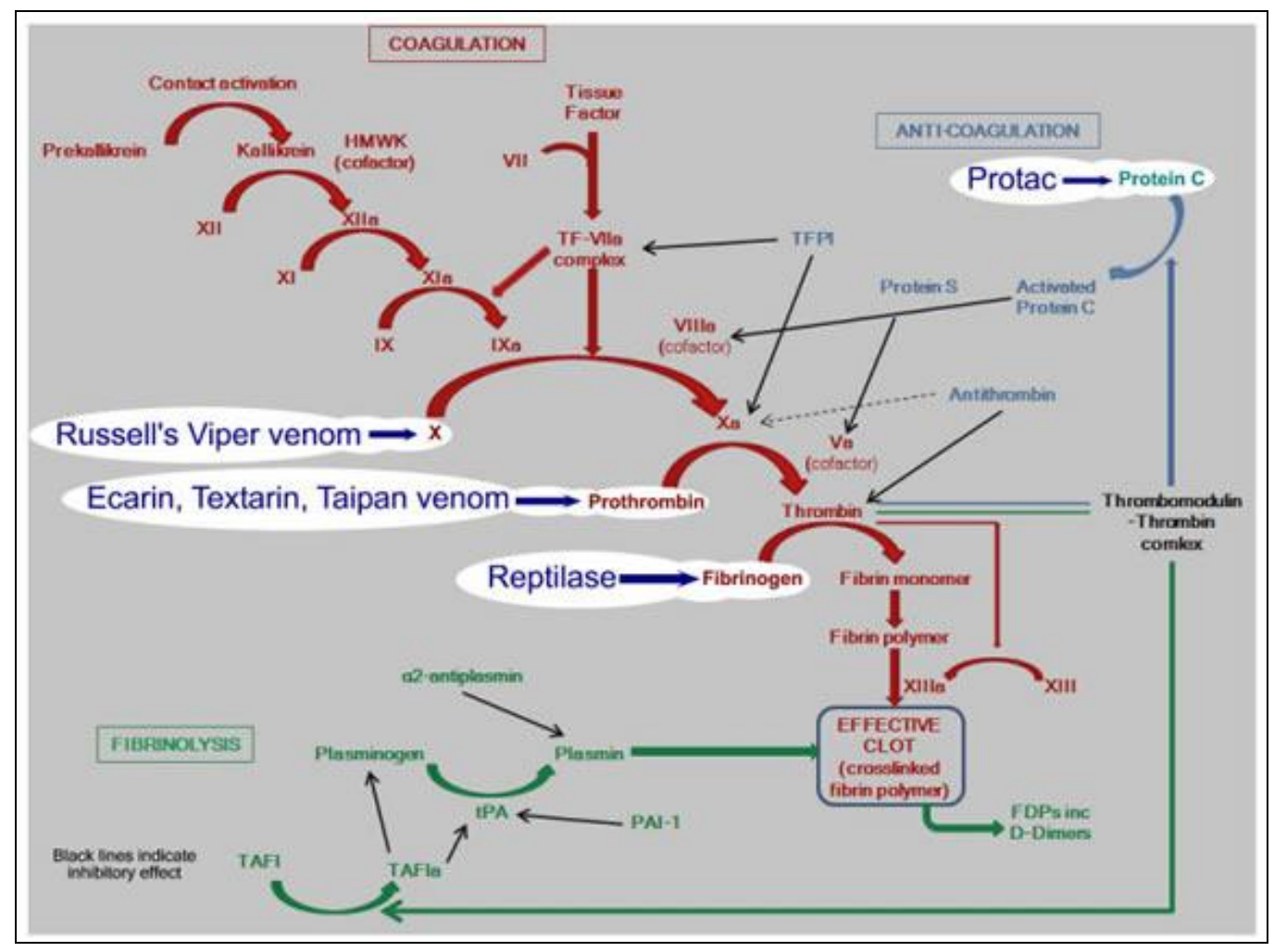

Gambar 2 Hubungan Bisa Ular dan Hemostasis

Dikutip dari : Hodgson ${ }^{13}$

Bisa ular dapat mengaktivasi faktor $\mathrm{X}$ menjadi Xa (aktif) atau mengubah protrombin menjadi trombin. Trombin akan mengubah fibrinogen menjadi fibrin. Keadaan ini akan menyebabkan terbentuknya trombus yang berlebihan serta meluas pada pembuluh darah. Trombus dapat menyebabkan gangguan mekanik pada membran eritrosit menyebabkan hemolisis intravaskuler. Penggunaan heparin pada kasus ini untuk mencegah proses koagulasi dengan inaktivasi trombin dan faktor Xa., ${ }^{411,13-16}$ 
Case Report

D-Dimer adalah produk akhir degradasi fibrin oleh plasmin yang terdiri atas dua fragmen D pada proses fibrinolisis sekunder. Plasmin memecahkan fibrin ikat silang sehingga dihasilkan fragmen $\mathrm{X}$ dan $\mathrm{D}$ dengan ukuran yang berbeda. Pada keadaan normal kadar D-Dimer dalam darah antara 8-135 ng/mL. Plasmin bekerja memecahkan fibrin dan fibrinogen. Pada fibrinolisis primerplasmin memecahkan fibrinogen dan menghasilkan fragmen X,Y, D dan E yang merupakan fibrinogen degradation products. Pada DIC pembentukan D-Dimer sebagai penanda adanya pembentukan trombin disertai pembentukan plasmin. ${ }^{5,11}$

Pemeriksaan kadar enzim AST (aspartat aminotransferase) penderita dalam batas normal yaitu $43 \mathrm{U} / \mathrm{L}(\mathrm{N}$ : < $50 \mathrm{U} / \mathrm{L})$ dan kadar enzim ALT (alanin aminotransferase) dalam batas normal yaitu $14 \mathrm{U} / \mathrm{L}(\mathrm{N}:<50 \mathrm{U} / \mathrm{L})$. Pemeriksaan enzim AST dan ALT dilakukan untuk menilai fungsi hepar penderita. Bila terjadi kerusakan hepatosit oleh karena pengaruh bisa ular, akan terjadi peningkatan enzim ALT dan AST. Fungsi hati penderita tidak mengalami gangguan yang disebabkan oleh bisa ular, sehingga sintesis fibrinogen tidak terganggu. ${ }^{14,18}$

Pemeriksaan ureum dan kreatinin untuk menilai fungsi ginjal. Pemeriksaan glukosa darah untuk menilai status glukosa darah penderita. Pada kasus ini hiponatremia $(128 \mathrm{mEq} / \mathrm{L})$ dapat terjadi karena pemberian cairan yang berlebihan. Penderita mendapat infus RL 1500 mL/hari. Warrell melaporkan kejadian hiponatremia pada penderita yang digigit oleh ular belang (Bungarus fasciatus). ${ }^{18}$

Serum anti bisa ular (SABU) adalah serum polivalen yang berasal dari plasma kuda yang dikebalkan terhadap bisa ular yang mempunyai efek neurotoksik dan hemotoksik yang ada di Indonesia. Indikasi SABU adalah untuk pengobatan terhadap gigitan ular berbisa. ${ }^{10,19}$

Tabel 6 Komposisi Serum Anti Bisa Ular

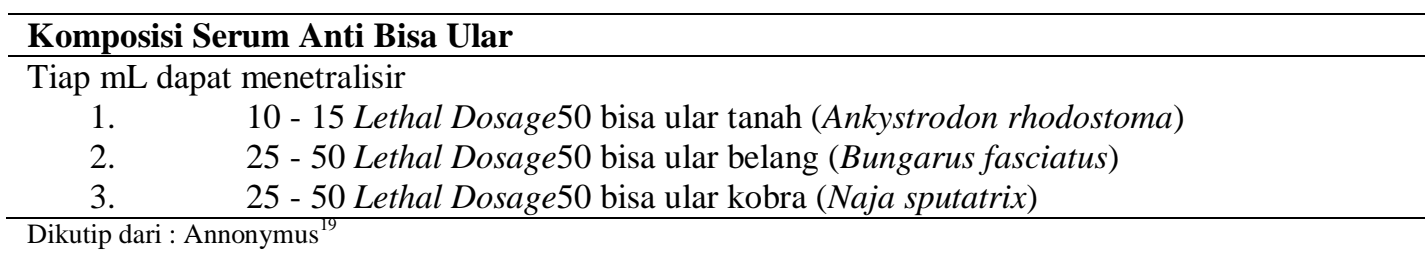

Dosis dan cara pemberian yang tepat sulit untuk ditentukan karena bergantung dari jumlah bisa ular yang masuk ke dalam peredaran darah penderita. Biasanya 
Case Report

diberikan dosis awal sebanyak 2 vial @ $5 \mathrm{ml}$ sebagai larutan 2\% dalam $\mathrm{NaCl} 0,9 \%$ dapat diberikan sebagai infus dengan kecepatan 40-80 tetes per menit, kemudian diulang setelah 6 jam. Apabila diperlukan (gejala akibat bisa ular misalnya perdarahan tidak berkurang atau bertambah) SABU dapat terus diberikan setiap 24 jam sampai maksimum (80-100 mL). Penyimpanan pada suhu $2-8^{\circ} \mathrm{C}$ dalam lemari es. ${ }^{16,17}$

Penderita dirawat selama 8 hari, setelah pemberian SABU terakhir pada tanggal 19 Mei 2011, keadaan umum penderita stabil, dan pada tanggal 22 Mei 2011 penderita diperbolehkan pulang.

\section{Simpulan}

Telah dibahas kasus seorang laki-laki berusia 76 tahun yang didiagnosis sebagai Vulnus Morsum Serpentum dengan Disseminated intravascular coagulation (DIC) dan hipertensi stage II. Kasus gigitan ular memerlukan penatalaksanaan yang cepat dan komprehensif sehingga dapat meminimalkan kemungkian kecacatan dan kematian.

\section{Daftar Pustak}

1. Warrell DA. Snake bite. Lancet. Review. 2010; 2375(9708):77-88.

2. Chobanian AV, Bakris GL, Black HR, Cushman WC, Green LA, Izzo JL Jr, et al. The seventh report of the joint national committee on prevention, detection, evaluation, and treatment of high blood pressure. Hypertension. 2003; 42(6):1206-52

4. Lazarchick J, Oswald M. Interaction of the fibrinolytic, coagulation, and kinin systems; Disseminated Intravascular Coagulation, In: Harmening DM, editor. Clinical Hematology and Fundamentals of Hemostasis. Edisi ke-5. Philadelphia: F.A.Davis Company; 2009.

5. Schwartz S. Disorders of plasma clotting factors. In: Harmening D, editor. Clinical Hematology and Fundamentals of Hemostasis. Edisi ke-5. Philadelphia: F.A. Davis Company; 2009. p. 607-11.

6. Kennedy MS. Transfusion therapy, In: Harmening DM, editor. Modern Blood Banking and Transfusion Practices. Edisi ke-6. Philadelphia: F.A. Davis Company; 2012.p. 355.

7. Sink BLS. Administration of blood components, In: Roback J, Grossman B, Harris T, Hillyer C, editor. AABB Technical Manual. Edisi ke-17. Maryland: AABB; 2011.p. 617-28.

8. Nester T, AuBuchon JP. Hemotherapy decisions and their outcomes, In: Roback JD, Grossman BJ, Harris T, Hillyer CD, editor. AABB Technical Manual. Edisi ke-17. Maryland: AABB; 2011.p. 571-604.

9. Wolber EM, Haase B, Jelkmann W. Thrombopoietin production in human hepatic cell cultures (HepG2) is resistant to IFN-alpha, IFN-beta, and IFN-gamma treatment. Journal of interferon \& cytokine research : the official journal of the International Society for Interferon and Cytokine Research. Comparative Study. 2002;22(12):1185-9.

10. Warrell DA. Guidelines for the management of snake bites. World Health Organization; 2010.

11. McPherson R. Specific proteins, In: McPherson R, Pincus M, editor. Henry's Clinical Diagnosis and Management by Laboratory Methods. Edisi ke-22. Philadelphia: Elsevier; 2011.p. 259-72.

12. Theusinger OM, Baulig W, Seifert B, Emmert MY, Spahn DR, Asmis LM. Relative concentrations of haemostatic factors and cytokines in solvent/detergent-treated and fresh-frozen plasma. British J Anaesth. 2011;106(4):505-11.

13. Hodgson WC, Wickramaratna JC. Snake venoms and their toxins: an Australian perspective. Toxicon: official Journal of the International Society on Toxinology. 2006;48(7):931-40.

14. Braud S, Bon C, Wisner A. Snake venom proteins acting on hemostasis. Biochimie. 2000;82(9-10):851-9.

15. Kini RM. Anticoagulant proteins from snake venoms: structure, function and mechanism. Biochem J. 2006;397(3):377-87. 


\section{Case Report}

16. Lu Q, Clemetson JM, Clemetson KJ. Snake venoms and hemostasis. Journal of thrombosis and haemostasis : JTH. Review. 2005;3(8):1791-9.

17. Mammen EF. The haematological manifestations of sepsis. The Journal of antimicrobial chemotherapy. Review. 1998;41 Suppl A:17-24.

18. Pincus M, Tierno P, Fenelus M, Bowne W, Bluth M. Evaluation of liver function. Dalam: R RM, Pincus M, editor. Henry's Clinical Diagnosis and Management by Laboratory Methods. Philadelphia: Elsevier; 2011. p. 296-310.

19. Annonymus. Serum Anti Bisa Ular (Kuda). 2015 [cited 04 Februari 2015]. Available from: http://www.biofarma.co.id/produk/serum-anti-bisa-ular-kuda-sera-2/ 